\title{
Medium- and long-chain fatty acid uptake and utilization by Streptomyces coelicolor A3(2): first characterization of a Gram-positive bacterial system
}

\author{
Claudia Banchio and Hugo C. Gramajo \\ Author for correspondence: Hugo C. Gramajo. Tel: +54 41 350661. Fax: +54 41390465. \\ e-mail: gramajo@unromb.edu.ar
}

Programa

Multidisciplinario de

Biologla Experimental

(PROMUBIE-CONICET) and

Departamento de

Microbiologra, Facultad de

Ciencias Bioquímicas y

Farmaceúticas, 'Universidad

Nacional de Rosario

Suipacha 531, 2000-

Rosario, Argentina
The first characterization of fatty acid uptake in a Gram-positive bacterium is reported. Streptomyces coelicolor A3(2) utilizes fatty acids of different chain length $\left(C_{4}-C_{18}\right)$ as sole carbon and energy sources. In vivo $\beta$-oxidation studies and the assay of two enzymes of the $\beta$-oxidation cycle proved that fatty acid degradation is constitutive in this micro-organism. Uptake of the mediumchain fatty acid octanoate showed the characteristics of simple diffusion, whereas the uptake of palmitate, a long-chain fatty acid, occurred by both simple diffusion and active transport. After correcting for non-mediated transport, palmitate uptake measured over a wide range of concentrations followed Michaelis-Menten kinetics. The apparent $K_{m}$ for palmitate was $97.8 \mu \mathrm{M}$ and the $V_{\max }$ was $19.3 \mathrm{nmol} \mathrm{min}^{-1}\left(\mathrm{mg}\right.$ protein) ${ }^{-1}$. Competition experiments showed specificity of the mediated transport component for long-chain fatty acids $\left(>\mathrm{C}_{10}\right.$ ). Metabolic inhibitors such as oligomycin, NaF and vanadate, and the ionophores gramicidin and carbonyl cyanide $\boldsymbol{m}$ chlorophenylhydrazone (CCCP) inhibited palmitate uptake to different degrees, consistent with the existence of an active transport mechanism. Uptake rates measured at different pH values indicated that both the ionized and the unionized forms of octanoate crossed the cytoplasmic membrane by simple diffusion. Palmitate in its ionized form appears to be transported by an active mechanism, whereas the unionized molecule diffuses through the membrane. When present in the medium, glucose stimulated the degradation of long-chain fatty acids by increasing the rate of uptake and the level of acylCoA synthetase.

Keywords: Streptomyces, fatty acids, transport, glucose stimulation, $\beta$-oxidation

\section{INTRODUCTION}

The genus Streptomyces consists of Gram-positive, obligately aerobic bacteria abundant in most soils. These micro-organisms exhibit a mycelial growth habit and rely for their nutrition on a variety of extracellular hydrolytic enzymes such as cellulases, hemicellulases, proteases and lipases (Korn-Wendisch \& Kutzner, 1991). These proteins allow Streptomyces spp. to use a wide range of complex insoluble substrates such as cellulose, hemicellulose, agar, and oils as carbon

Abbreviations: CCCP, carbonyl cyanide $m$-chlorophenylhydrazone; PMS, phenazine methosulphate. sources. While considerable data exist on these hydrolytic exoenzymes (Peczynska-Czoch \& Mordarski, 1988 ), very little is known about the way their breakdown products enter the cell. Streptomycetes are also well able to utilize more readily available materials, such as simple sugars (Hodgson, 1982). Glucose is often preferred to other carbon sources, and as was shown in S. coelicolor A3(2), this preference is exerted either through repression of genes involved in the uptake of alternative carbon sources, including arabinose (Hodgson, 1982), glycerol (Smith \& Chater, 1988) and galactose (Fornwald et al., 1987), or by repressing the production of extracellular polysaccharide-degrading enzymes such as agarase (Hodgson, 1982; ServínGonzalez \& Bibb, 1994), $\alpha$-amylase (Virolle \& Bibb, 
1988) and chitinase (Miyashita et al., 1991; Robbins et al., 1992; Virolle \& Bibb, 1988; Delic et al., 1992).

Streptomycetes used for industrial purposes are commonly grown on different oils and fats as carbon sources. Nevertheless no reports exist, to our knowledge, on how free fatty acids released from these substrates by the lipases (Pérez et al., 1993) are imported and degraded by these micro-organisms. To study the ability of streptomycetes to utilize different chain-length fatty acids as sole carbon and energy sources, and to characterize their uptake system biochemically, we have chosen Streptomyces coelicolor A3(2), genetically the best characterized species (Hopwood et al., 1994).

\section{METHODS}

Bacterial strains, media and growth conditions. $S$. coelicolor A3(2) strains were M145 (SCP1- SCP2-), J1501 (bisA1 uraA1 strA1 pgl SCP1- SCP2- ${ }^{-}$Hopwood et al., 1985) and M600 (SCP1- ${ }^{-} \mathrm{SCP}^{-}$; M. Bibb, personal comunication). S. lividans TK24 (Hopwood et al., 1983), S. glaucescens ETH (wild-type) and $S$. avermitilis ATCC (wild-type) were kindly provided by Professor D. Hopwood (John Innes Centre, Norwich, UK). Spores were prepared on soya flour medium and stored as spore suspensions in $20 \%(\mathrm{v} / \mathrm{v})$ glycerol at $-20^{\circ} \mathrm{C}$. Bacteria were grown in liquid minimal medium (SMM, Takano et al., 1992) or solid minimal medium MM (Hopwood et al., 1985). Carbon sources were sterilized separately and added to the culture medium prior to inoculation. Fatty acids were neutralized with $\mathrm{KOH}$ and added at a final concentration of $0.1 \%$ in the presence of $1 \%(\mathrm{v} / \mathrm{v})$ Brij 58 . Glucose and other sugars were used at a final concentration of $1 \%(\mathrm{w} / \mathrm{v})$.

Assay of fatty acid transport. Bacteria were grown overnight in SMM-Brij containing $0.1 \%$ oleate $\left(\mathrm{C}_{18: 1}\right)$ and $0.5 \%$ Casamino acids at $30^{\circ} \mathrm{C}$ and 250 r.p.m. Cells were harvested by centrifugation at $5000 \mathrm{~g}$ for $10 \mathrm{~min}$ at $4^{\circ} \mathrm{C}$, washed twice with SMM-Brij without Casamino acids, resuspended in the same medium, and briefly left on ice. Prior to assay, cells were preincubated for $10 \mathrm{~min}$ at $18^{\circ} \mathrm{C}$ in a water bath, and depending on the study, $1-{ }^{14} \mathrm{C}$-labelled fatty acids were added to the cell suspensions.

For the uptake studies, after the addition of the $1-{ }^{14} \mathrm{C}$-labelled fatty acid, $0.5 \mathrm{ml}$ samples were removed at different time points and rapidly filtered at room temperature through Amicon $0.45 \mu \mathrm{m}$ pore size membrane filters. Filtered cells were washed with $5 \mathrm{ml}$ SMM-Brij and put into scintillation vials containing $1 \mathrm{ml}$ liquid scintillation fluid. Radioactivity in the vials was measured with a liquid scintillation counter. The binding of radiolabelled fatty acids to the filters was only just above background detectable levels.

For kinetic studies, different concentrations (from 10 to $800 \mu \mathrm{M}$, final concentration) of $1{ }^{14} \mathrm{C}$-labelled fatty acids were added to the cell suspensions and, after $30 \mathrm{~s}, 0.5 \mathrm{ml}$ samples were removed, filtered and treated as described above.

For the competition assay, cells were treated as in the uptake studies. Before the addition (to $200 \mu \mathrm{M}$ final concentration) of labelled fatty acid, unlabelled fatty acids of different chain length were added at the same concentration and $0.5 \mathrm{ml}$ samples removed after $30 \mathrm{~s}$. One sample without the addition of unlabelled fatty acid was taken as a control.

In studies involving inhibitors or glucose, cells were preincubated under the conditions of transport followed by $5 \mathrm{~min}$ incubation in the presence of these effectors.
For studies involving $\mathrm{pH}$, cells were resuspended in SMM-Brij with different buffers to obtain various $\mathrm{pH}$ values $(4-10)$, followed by $10 \mathrm{~min}$ preincubation in the same buffer under the conditions of transport.

The results presented are the mean of at least three independent experiments.

Assay of- $\beta$-oxidation. In vivo fatty acid degradation was monitored by determining the amount of ${ }^{14} \mathrm{CO}_{2}$ formed from $1-{ }^{14} \mathrm{C}$-labelled fatty acids. Cells were grown and washed as described for fatty acid transport, and then resuspended and preincubated for $10 \mathrm{~min}$ at $30^{\circ} \mathrm{C}$ in SMM-Brij without Casamino acids and glucose. Rubber-stoppered $25 \mathrm{ml}$ Erlenmeyer flasks containing centre wells with $0.2 \mathrm{ml} 2 \mathrm{M} \mathrm{NaOH}$ to trap evolved $\mathrm{CO}_{2}$ were used for the assay. $1{ }^{14} \mathrm{C}$-labelled fatty acids were added to cell suspensions, and at different times $0.5 \mathrm{ml} 2.5 \mathrm{M} \mathrm{H}_{2} \mathrm{SO}_{4}$ (for assay with long-chain fatty acid) or phosphate/citrate buffer $\mathrm{pH} \mathbf{4 \cdot 2}$ (for medium-chain fatty acid) was added to the cell suspensions to stop the reaction. Flasks were incubated for a further $60 \mathrm{~min}$ to ensure complete evolution and trapping of $\mathrm{CO}_{2}$. The centre wells were removed and placed directly in scintillation vials containing $1 \mathrm{ml}$ liquid scintillation fluid, and radioactivity was measured in a liquid scintillation counter. Values from control flasks lacking cells were subtracted as background for each condition assayed.

Enzyme assay. Acyl-CoA synthetase (EC 6.2.1.3) was assayed by a modification of the procedure of Tanaka $e t$ al. (1979). Cells were grown in SMM-oleate and SMM-glucose, and crude extracts were prepared by disruption in a sonicator. The reaction mixture contained $0 \cdot 1 \mathrm{M}$ Tris $/ \mathrm{HCl}(\mathrm{pH} 7 \cdot 2$ ), $1.6 \mathrm{mM}$ Triton X-100, $0.15 \mathrm{M} \mathrm{KCl}, 10 \mathrm{mM} \mathrm{MgCl}, 10 \mathrm{mM}$ ATP, $1 \mathrm{mM}$ CoASH, crude extract $(200 \mu \mathrm{g}$ protein), and $0.2 \mu \mathrm{mol} 1{ }^{14} \mathrm{C}$-labelled fatty acid in $2 \mu \mathrm{l}$ propylene glycol. The reaction mixtures were preincubated for $5 \mathrm{~min}$ at $35^{\circ} \mathrm{C}$ and the reaction was initiated by the addition of crude extract. At different time points the reaction was stopped by adding 2.5 ml 2-propanol:heptane $\mathrm{H}_{2} \mathrm{SO}_{4} 1 \mathrm{M}(40: 20: 1)$ and vortexing. After addition of $1 \mathrm{ml} \mathrm{H}_{2} \mathrm{O}$ and $1 \mathrm{ml}$ heptane, the organic phase was separated by centrifugation and removed. After three extractions the radioactivity present in the aqueous phase was measured in a liquid scintillation counter. Values from control experiments lacking crude extracts were subtracted as background for each condition assayed.

Acyl-CoA dehydrogenase (EC 1.3.99.3) activity was measured by a change in the $A_{530}$ of formazan dye. The reaction mixture contained $40 \mathrm{mM}$ Tris $/ \mathrm{HCl}$ buffer $(\mathrm{pH} 8.0), 0.05 \%$ $(\mathrm{w} / \mathrm{v})$ phenazine methosulphate (PMS), $0.2 \%$ (w/v) Triton X$100,1 \mathrm{mM}$ palmitoyl-CoA (Sigma), 0.4 mM nitrotetrazolium blue and cell extract, in a total volume of $0.1 \mathrm{ml}$. The reaction was started by addition of PMS solution and carried out at $37^{\circ} \mathrm{C}$. At different times the reaction was terminated by addition of $0.1 \mathrm{M} \mathrm{HCl}$ and $10 \%(\mathrm{v} / \mathrm{v})$ Triton $\mathrm{X}-100$, and the $A_{530}$ measured. One unit of acyl-CoA dehydrogenase activity was defined as the amount of enzyme required to oxidize $1 \mathrm{mmol}$ palmitoyl-CoA $\mathrm{min}^{-1}$.

\section{RESULTS}

\section{Growth of S. coelicolor A3(2) on various fatty acids as sole carbon source}

The ability of $S$. coelicolor A3(2) to grow on fatty acids of various chain lengths as sole carbon and energy source was studied in liquid minimal medium supplemented with different concentrations of various fatty 
Table 1. Rate of $\beta$-oxidation of $300 \mu \mathrm{M}$ of labelled fatty acids by $S$. coelicolor M145 grown in SMM-oleate or SMM-glucose

The results are means of three independent determinations.

\begin{tabular}{|c|c|c|}
\hline \multirow[t]{2}{*}{ Carbon source } & \multicolumn{2}{|c|}{ 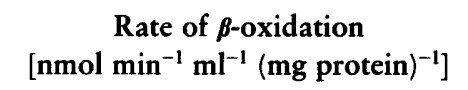 } \\
\hline & {$\left[{ }^{14} \mathrm{C}\right]$ Palmitate } & {$\left[{ }^{14} \mathrm{C}\right]$ Octanoate } \\
\hline Oleate & $2 \cdot 825$ & $2 \cdot 050$ \\
\hline Glucose & $4 \cdot 500$ & 1.950 \\
\hline
\end{tabular}

acids with an even number of carbon atoms. S. coelicolor M145 grew on all of the fatty acids tested, from $\mathrm{C}_{4}$ to $\mathrm{C}_{18}$, with the best growth yields for most of these carbon sources at concentrations of $0 \cdot 1 \%(\mathrm{w} / \mathrm{v})$. Decanoate and dodecanoate, however, were toxic at these concentrations and for these fatty acids the best growth yields were obtained at $0.02 \%(\mathrm{w} / \mathrm{v})(1.2 \mathrm{mM})$ and $0.05 \%$ $(\mathrm{w} / \mathrm{v})(2.5 \mathrm{mM})$ respectively. Similar observations were made in Escherichia coli but hexanoate and octanoate were toxic at concentrations higher than $5 \mathrm{mM}$ (Nunn $e t$ al., 1979). We were unable to determine the growth rates of the cultures for each of the fatty acids used, since the mycelia clumped markedly in the presence of these carbon sources, giving highly non-homogeneous cultures and preventing the accurate determination of growth parameters.

\section{In vivo $\beta$-oxidation studies}

To determine whether the $\beta$-oxidation enzyme system was constitutive or induced by fatty acids in $S$. coelicolor, we measured the rate of ${ }^{14} \mathrm{CO}_{2}$ released from labelled fatty acids incubated with M145 cultures pregrown in SMM-oleate or in SMM-glucose (Table 1). Both fatty acids used in the assay, $\left[{ }^{14} \mathrm{C}\right]$ palmitate $\left(\mathrm{C}_{16: 0}\right)$ and $\left[{ }^{14} \mathrm{C}\right]$ octanoate $\left(\mathrm{C}_{8: 0}\right)$, were effectively oxidized by cells grown either in the presence or in the absence of the fatty acid. ${ }^{14} \mathrm{CO}_{2}$ was readily detected after $1 \mathrm{~min}$ incubation and the reaction was linear for at least $15 \mathrm{~min}$ under the conditions of the assay. Since ${ }^{14} \mathrm{CO}_{2}$ was detected as early as $1 \mathrm{~min}$ after the addition of fatty acid to glucose-grown cultures an induction of the $\beta$ - oxidation enzyme system by the fatty acid added seems unlikely. Surprisingly, the rate of palmitate $\beta$-oxidation by cultures grown on glucose was almost twofold higher than that of cultures grown on oleate, as deduced from the rates of ${ }^{14} \mathrm{CO}_{2}$ released from these cultures (Table 1 ). $\beta$-Oxidation of octanoate was also detected in cultures growing on either SMM-oleate or SMM-glucose, but the apparent stimulation of palmitate $\beta$-oxidation by glucose-grown cultures was not observed for octanoate (Table 1).

\section{Activities of acyl-CoA synthetase and acyl-CoA dehydrogenase}

The uptake and degradation of fatty acids to single acetyl-CoA units through the fatty acid $\beta$-oxidation cycle involves five enzymes: acyl-CoA synthetase, acylCoA dehydrogenase, enoyl-CoA hydratase, 3-hydroxacyl-CoA dehydrogenase and 3-ketoacyl-CoA thiolase (Clark \& Cronan, 1996). To determine whether the enzymes of the $\beta$-oxidation cycle were expressed constitutively in $S$. coelicolor or induced in the presence of fatty acids, acyl-CoA synthetase and acyl-CoA dehydrogenase were assayed in crude extracts prepared from oleate- or glucose-grown cultures. The results in Table 2 clearly indicate that both proteins were present constitutively in $S$. coelicolor. The specific activity of the acyl-CoA dehydrogenase was very similar in extracts prepared from glucose- or from oleate-grown cultures; however, the levels of acyl-CoA synthetase, the enzyme which activates exogenous fatty acids into metabolically active CoA thioesters, were sixfold higher in cultures grown on glucose. The increase of palmitate $\beta$-oxidation in glucose-grown cultures (Table 1) could hence be partially explained by the increase in the level of acylCoA synthetase activity. However, as we have not measured all of the enzymes of the cycle, we do not know whether this represents the only enzyme of the cycle that increases in the presence of glucose.

\section{Oleate utilization is stimulated specifically by glucose in solid MM}

The higher activity of acyl-CoA synthetase and the higher rates of ${ }^{14} \mathrm{CO}_{2}$ released from cultures grown in glucose led us to analyse the effect of different carbon sources on the utilization of oleate in solid MM. Fig. 1 shows that glucose, but not galactose, stimulated oleate

Table 2. Acyl-COA synthetase and acyl-CoA dehydrogenase activity in crude protein extracts prepared from cells of S. coelicolor M145 grown in SMM-glucose or SMM-oleate

The results are means of three determinations \pm SE.

\begin{tabular}{|c|c|c|}
\hline Carbon source & $\begin{array}{l}\text { Acyl-CoA synthetase } \\
\left(\text { pmol } \mathrm{min}^{-1} \mathrm{ml}^{-1}\right)\end{array}$ & $\begin{array}{c}\text { Acyl-CoA dehydrogenase } \\
{\left[\mathrm{U}(\mathrm{mg} \text { protein })^{-1}\right]}\end{array}$ \\
\hline Oleate & $8 \cdot 3 \pm 0.5$ & $35 \cdot 0 \pm 0 \cdot 5$ \\
\hline Glucose & $95 \cdot 0 \pm 1 \cdot 0$ & $40 \cdot 0 \pm 0.5$ \\
\hline
\end{tabular}



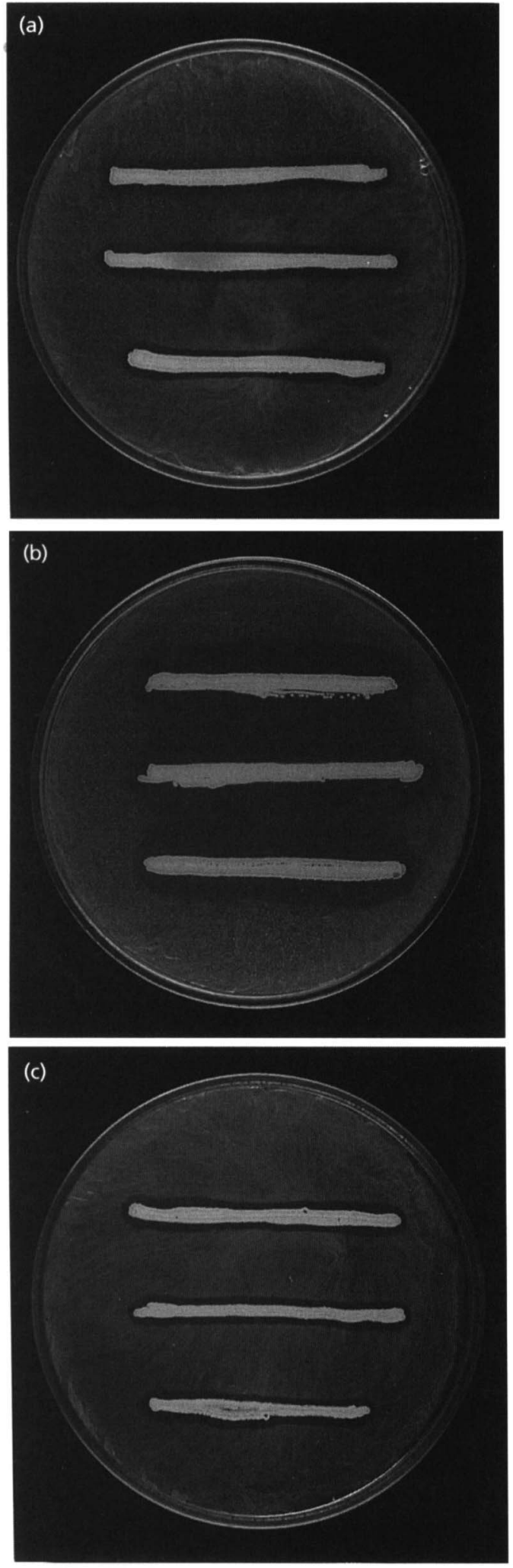

Fig. 1. Breakdown of oleate (clear halo) by S. coelicolor M145 grown in solid MM with (a) oleate, (b) oleate/glucose or (c) oleate/galactose as sole carbon source. consumption. Several other carbon sources, including xylose, fructose, arabinose, mannitol, acetate and glycerol, were also tested, but none of them stimulated the utilization of oleate. The same results were obtained with different strains of $S$. coelicolor, e.g. 1190, M600 and $\mathrm{J} 1501$, indicating that it was not a strain-related phenomenon. Other Streptomyces species, such as $S$. lividans, S. glaucescens and S. avermitilis, could also utilize oleic acid as a sole carbon source; however, only $S$. lividans, the most closely related species to $S$. coelicolor A3(2) (Stackebrandt et al., 1992) showed a stimulation of oleate consumption by glucose.

\section{Kinetics of fatty acid uptake}

The rate of uptake of $\left[{ }^{14} \mathrm{C}\right]$ palmitate and $\left[{ }^{14} \mathrm{C}\right]$ octanoate, as examples of long- and medium-chain fatty acids, were studied in cultures of M145 grown on SMM-oleate or SMM-glucose. The rates of uptake of both fatty acids were linear for the first $60 \mathrm{~s}$ at $18^{\circ} \mathrm{C}$, and during this time a negligible loss of ${ }^{14} \mathrm{CO}_{2}$ due to $\beta$-oxidation was observed. After this period of time, evolution of ${ }^{14} \mathrm{CO}_{2}$ became significant, causing a decrease in the rate of cellular accumulation of labelled fatty acids.

Once the conditions for measuring initial velocities $\left(v_{\mathrm{i}}\right)$ had been established, the kinetics of transport of longand medium-chain fatty acids were studied by measuring the rate of uptake of palmitate or octanoate at different concentrations $(10-400 \mu \mathrm{M})$. The rate of palmitate uptake increased with increasing substrate concentration, and no saturation was observed. Between 10 and $100 \mu \mathrm{M}$ palmitate, its rate of uptake was directly proportional to the external fatty acid level. These linear kinetics were confirmed by a linear regression analysis. Above $100 \mu \mathrm{M}$ the rate of uptake increased abruptly (Fig. 2a), indicating the existence of a more complex kinetics with at least two components involved in the uptake system for palmitate. Addition of $250 \mu \mathrm{M}$ oligomycin did not affect the uptake rate at low concentrations of the fatty acid, but it severely reduced the rate of uptake at concentrations above $100 \mu \mathrm{M}$. Linear kinetics were observed under inhibitory conditions, exhibiting the same velocity as the first part of the profile. The fact that linear uptake was observed in the presence of oligomycin provides strong evidence that the linear component of palmitate uptake was due to diffusion. When this linear component was subtracted from the uptake occurring in the absence of the inhibitor for each palmitate concentration, saturable uptake kinetics were observed (Fig. 2a), which conformed to Michaelis-Menten kinetics. Values for the Michaelis constant $\left(K_{\mathrm{m}}\right)$ and for the maximum velocity $\left(V_{\max }\right)$, obtained by using a computer-assisted non-linear regression analysis, were $K_{\mathrm{m}}=97.8 \pm 23.3 \mu \mathrm{M}$ and $V_{\max }$ $=19 \cdot 3 \pm 1.7 \mathrm{nmol} \mathrm{min}{ }^{-1}$ (mg protein) ${ }^{-1}$ (means $\pm \mathrm{SE}$ ). Attempts to fit the data to the Hill equation, or a double hyperbola, were both unsuccessful.

The rate of uptake of octanoate was directly proportional to the external concentration of the fatty acid, and no saturation was observed within the concen- 

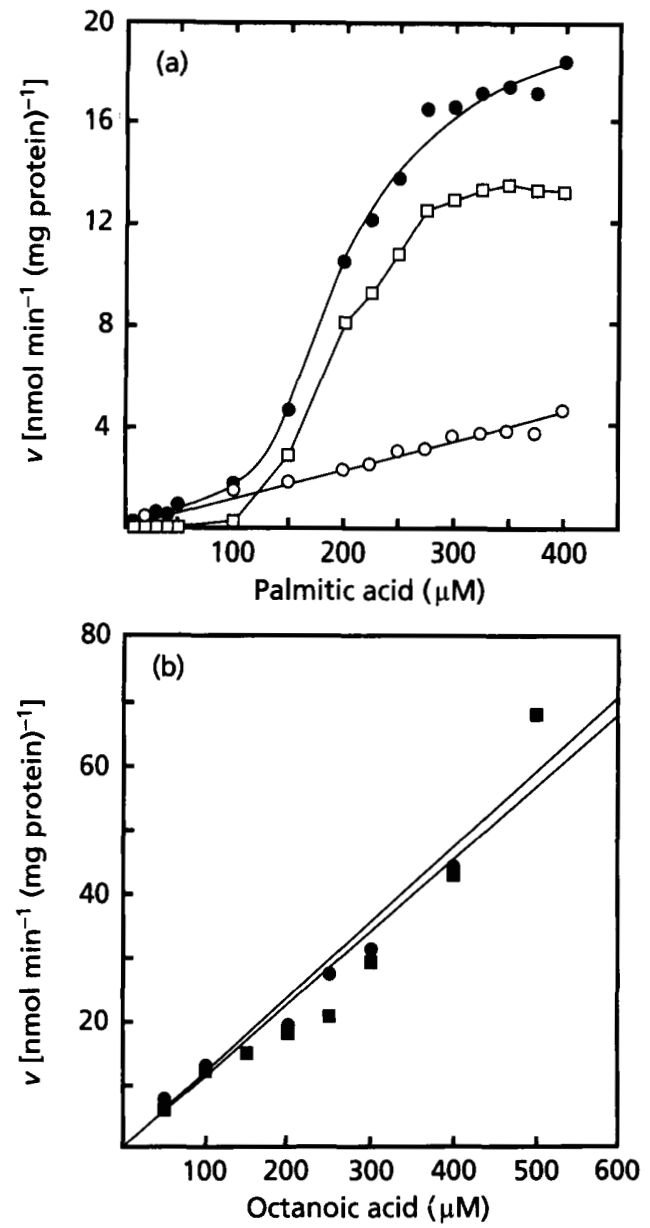

Fig. 2. Effect of substrate concentration on the uptake of palmitate by $S$. coelicolor in the absence or presence of $250 \mu \mathrm{M}$ oligomycin. (a) Uptake occurring in the presence of oligomycin (O) was subtracted from uptake under non-inhibitory conditions (O) for each palmitate concentration, to give the mediated uptake ( $\square$ ). (b) Effect of substrate concentration on the uptake of octanoate by $S$. coelicolor in the absence (O) or presence $(\square)$ of $250 \mu \mathrm{M}$ oligomycin.

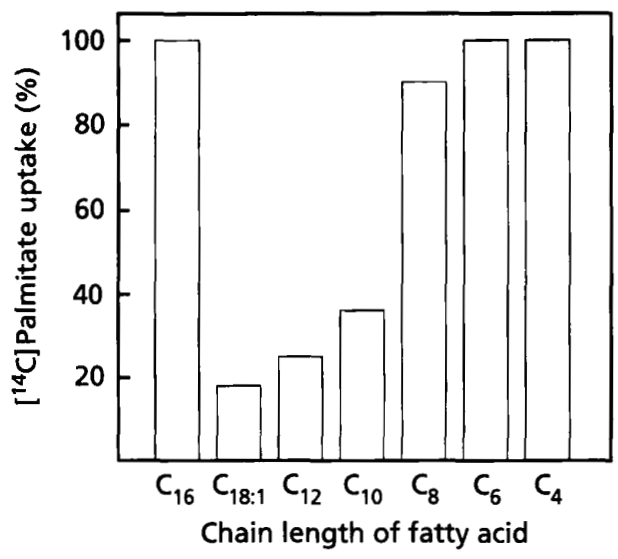

Fig. 3. Relative uptake of labelled palmitate by $S$. coelicolor in the presence of various other fatty acids. The rate of uptake in the absence of competitors was taken as $100 \%$. Data are means of two replicates.

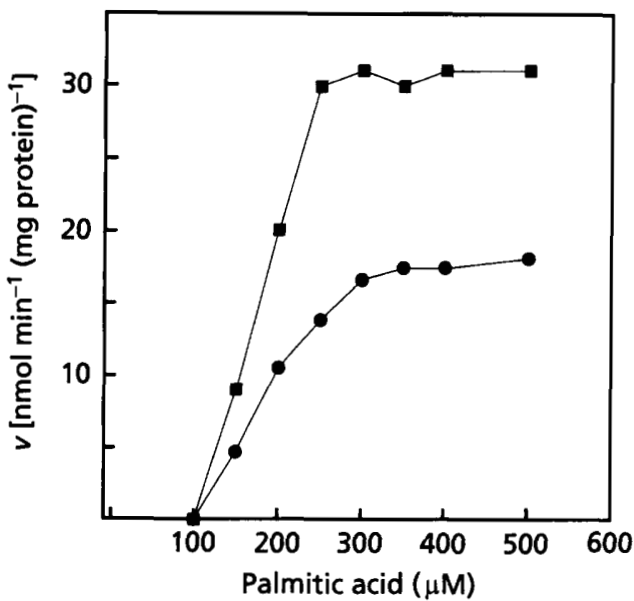

Fig. 4. Effect of substrate concentration on the uptake of palmitate in the absence or presence of glucose. Uptake of palmitate from $50-500 \mu \mathrm{M}$ solutions was assayed with $(\square)$ or without (O) glucose $(1 \%, w / v)$ under standard conditions. Values obtained under inhibitory conditions $(250 \mu \mathrm{M}$ oligomycin) were subtracted for each of the concentrations assayed.

trations assayed (Fig. 2b). The $K_{d}$ obtained from the slope of the curve was $0 \cdot 12$. A double reciprocal plot of these uptake data passed through the origin, suggesting that octanoate uptake corresponds to simple diffusion. In agreement with this, oligomycin failed to inhibit uptake of octanoate.

To determine the specificity of the long- and mediumchain fatty acid uptake systems, we compared the effect of unlabelled fatty acids on the uptake of $200 \mu \mathrm{M}$ $\left[{ }^{14} \mathrm{C}\right]$ palmitate or $\left[{ }^{14} \mathrm{C}\right]$ octanoate. Fig. 3 shows that palmitate uptake was severely inhibited by other longchain fatty acids, and to a small extent by a $\mathrm{C}_{10}$ fatty acid, whereas octanoate did not compete significantly with the uptake of palmitate. On the other hand, octanoate uptake was not inhibited by any of the fatty acids tested in this assay (data not shown). These results also support the idea that long-chain fatty acids have, besides a diffusion uptake mechanism, a mediated transport system, while medium-chain fatty acids simply diffuse into the cells.

\section{Glucose stimulation of long-chain fatty acid uptake}

Since utilization of long-chain fatty acids was clearly stimulated by glucose, we studied the effect of this monosaccharide on the uptake of palmitate and octanoate. For this purpose, we measured the rate of uptake of the two labelled fatty acids at different concentrations. Cultures were grown in SMM-oleate, and uptake was assayed with cells which were resuspended and preincubated for $5 \mathrm{~min}$ in the uptake buffer with or without glucose. The uptake of palmitate was clearly stimulated (nearly twofold) in the presence of glucose (Fig. 4); this stimulation became significant only above $100 \mu \mathrm{M}$ fatty acid, coinciding with the activation of the mediated component of the transport mechanism (Fig. 2a). The 
Table 3. Effect of metabolic inhibitors on fatty acid transport

Uptake of $400 \mu \mathrm{M}$ labelled fatty acid was assayed in the presence of increasing concentrations of several inhibitors. Data are expressed as means \pm SE of three replicates.

\begin{tabular}{|c|c|c|}
\hline Inhibitor & Concn & $\begin{array}{l}\text { Percentage inhibition of } \\
{\left[{ }^{14} \mathrm{C}\right] \text { palmitate uptake }}\end{array}$ \\
\hline \multirow[t]{2}{*}{ СССР } & $50 \mu \mathrm{M}$ & $24 \cdot 6 \pm 1 \cdot 0$ \\
\hline & $100 \mu \mathrm{M}$ & $40 \cdot 0 \pm 1 \cdot 0$ \\
\hline \multirow[t]{2}{*}{ Valinomycin } & $1 \mu \mathrm{M}$ & $37 \cdot 7 \pm 0.5$ \\
\hline & $5 \mu \mathrm{M}$ & $59 \cdot 0 \pm 1 \cdot 0$ \\
\hline \multirow[t]{2}{*}{ Gramicidin } & $5 \mu \mathrm{M}$ & $45 \cdot 0 \pm 1 \cdot 0$ \\
\hline & $50 \mu \mathrm{M}$ & $43 \cdot 0 \pm 1 \cdot 0$ \\
\hline \multirow[t]{2}{*}{ Oligomycin } & $25 \mu \mathrm{M}$ & $18 \cdot 0 \pm 0 \cdot 5$ \\
\hline & $250 \mu \mathrm{M}$ & $78 \cdot 0 \pm 0.5$ \\
\hline \multirow[t]{3}{*}{ Vanadate } & $50 \mu \mathrm{M}$ & $36 \cdot 0 \pm 1 \cdot 0$ \\
\hline & $100 \mu \mathrm{M}$ & $41 \cdot 0 \pm 1 \cdot 0$ \\
\hline & $500 \mu \mathrm{M}$ & $50 \cdot 0 \pm 1 \cdot 0$ \\
\hline \multirow[t]{2}{*}{$\mathrm{NaF}$} & $1 \mathrm{mM}$ & $64 \cdot 4 \pm 1 \cdot 0$ \\
\hline & $10 \mathrm{mM}$ & $78 \cdot 0 \pm 1 \cdot 0$ \\
\hline
\end{tabular}

only kinetic parameter that changed in the presence of glucose was the $V_{\max }$, which increased 1.9-fold, while the $K_{\mathrm{m}}$ remained unchanged. When galactose was utilized instead of glucose, no stimulation in the rate of palmitate uptake was detected (data not shown), consistent with the results obtained in solid MM (Fig. 1).The rate of uptake of octanoate was not altered by the presence of glucose (data not shown), agreeing with the data for $\beta$-oxidation of this fatty acid (Table 1 ). The stimulatery effect of glucose on the uptake and $\beta$ oxidation of fatty acids thus seems to affect exclusively the mediated component of the long-chain fatty acid transport system.

\section{Effect of metabolic inhibitors on fatty acid transport}

The energy requirements for fatty acid transport were studied by measuring the effect of several metabolic inhibitors on the uptake of octanoate and palmitate (Table 3). Gramicidin, an ionophore which forms channels in the membrane and induces changes in the two components of the protonmotive force, produced a maximum of $45 \%$ inhibition of long-chain fatty acid uptake when used at a concentration of $5 \mu \mathrm{M}$. The protonophore CCCP, which depletes the protonmotive force by increasing $\mathrm{H}^{+}$influx and thereby inducing acidification of the cytosol, also showed an inhibitory effect on the uptake of palmitate and the percentage inhibition was similar to that found for gramicidin. Vanadate, a specific inhibitor of the membrane $\mathrm{H}^{+}$ATPases, inhibited palmitate uptake at all concentrations tested. Nonetheless, even at very high concentrations of vanadate $(500 \mu \mathrm{M})$, only $50 \%$ inhibition was obtained. The strongest inhibitory effects were seen with substances that directly reduce the internal levels of ATP: the antibiotic oligomycin (an ATP synthase
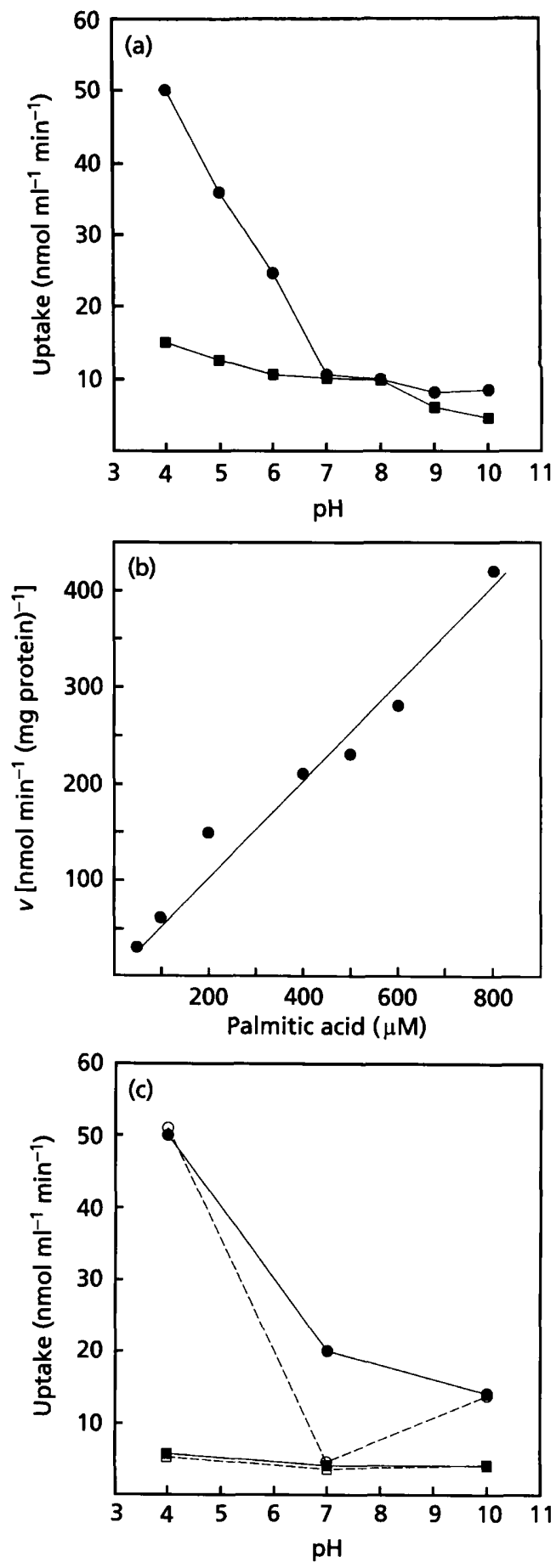

Fig. 5. (a) Uptake rates of palmitate (O) and octanoate ( $($ ) were determined by using $200 \mu \mathrm{M}$ of each of the fatty acids at various extracellular $\mathrm{pH}$ values. (b) Effect of substrate concentration $(50-800 \mu \mathrm{M})$ on the uptake of palmitate at extracellular pH 4. (c) Effect of $\mathrm{NaF}$ on the uptake of palmitate at different concentrations and at various extracellular $\mathrm{pH}$ values. Uptake of palmitate at $50(\square, \square)$ or $400(0,0) \mu \mathrm{M}$ was assayed alone $(\square, 0)$ or in the presence of $10 \mathrm{mM} \mathrm{NaF}(\square, 0)$.

inhibitor), and $\mathrm{NaF}$ (which inhibits glycolysis): both produced a maximum of $78 \%$ inhibition. These experiments clearly indicate that the uptake of palmitate is an 
active process and that ATP hydrolysis is most probably the direct driving force. Octanoate uptake, however, was not inhibited by any of these ionophores or metabolic inhibitors, consistent with a simple diffusion mechanism for this medium-chain fatty acid.

\section{Effect of pH on fatty acid uptake}

The rate of long- and medium-chain fatty acid uptake was determined at different $\mathrm{pH}$ values to establish whether the ionized or the unionized form of the fatty acids was transported by the Streptomyces uptake system. The range of $\mathrm{pH}$ values used was outside those over which the organism grows, but nonetheless, as shown in Fig. 5(a), there were no significant variations in the rate of uptake of octanoate within the range of $\mathrm{pH}$ values assayed. However, for palmitate the highest rate of uptake was obtained at $\mathrm{pH} 4$, decreasing significantly at higher $\mathrm{pH}$ values. The fact that both long- and medium-chain fatty acids have a $\mathrm{pK}_{\mathrm{a}}$ of 4.8 (Weast, 1973) indicates that the transported species at $\mathrm{pH} 4$ corresponds to the unionized form of the fatty acid, whereas at $\mathrm{pH} 7$ most of the substrate is present in its ionized (anionic) form. The kinetic studies done with octanoate at $\mathrm{pH} 7$ indicated that this fatty acid was most probably transported by a simple diffusion mechanism. Therefore the similar rates of uptake for the ionized and the unionized forms of this fatty acid suggest that both species are transported by the same mechanism. Interestingly, palmitate was transported more efficiently at $\mathrm{pH} 4$ at the concentrations used in this assay $(200 \mu \mathrm{M})$, showing an important difference in the uptake of the ionized and the uninonized forms of the fatty acid. This led us to check the kinetics of palmitic acid uptake at $\mathrm{pH} 4$ (Fig. 5b). Initial uptake rates of the labelled fatty acid as a function of its concentration were linear and did not show saturation kinetics at least until $800 \mu \mathrm{M}$. A double reciprocal plot of these data yielded a line that passed though the origin. These results suggest that the uptake of the undissociated form of this long-chain fatty acid occurs by simple diffusion, in strong contrast with the uptake mechanism of the ionized species, which seems to be transported by both simple diffusion and an active transport mechanism (Fig. 3a). To test this hypothesis further, we measured initial rates of palmitate uptake at two different concentrations (50 and $400 \mu \mathrm{M})$, at different $\mathrm{pH}$ values and in the presence or absence of fluoride (Fig. 5c). These experiments showed that at $50 \mu \mathrm{M}$ there was no important difference in the rate of uptake at different $\mathrm{pHs}$, and $\mathrm{NaF}$ did not inhibit incorporation of the labelled fatty acid. At $400 \mu \mathrm{M}$, the rates of uptake at $\mathrm{pH} 4$ and 10 were not modified by the presence of fluoride, while at $\mathrm{pH} 7$ uptake was clearly inhibited.

\section{DISCUSSION}

The studies presented in this paper characterize the uptake and oxidation of long- and medium-chain fatty acids by $S$. coelicolor A3(2). It is worth mentioning that the only bacterium in which fatty acid transport and degradation have been studied in detail so far is E. coli (for a review see Nunn, 1986; Black \& DiRusso, 1994; Clark \& Cronan, 1996). Interestingly, the fatty acid system characterized in this Gram-negative bacterium seem to differ in many respects from the one we describe here.

Our studies indicate that $S$. coelicolor strain M145 can effectively utilize exogenous fatty acids of different chain length, from $\mathrm{C}_{4}$ to $\mathrm{C}_{18}$, as sole carbon and energy sources. In contrast, $E$. coli can only grow on fatty acids of 12 or more carbons and then only after a distinct lag period, required for induction of the fad regulon (Overath et al., 1967, 1969). Medium-chain fatty acids (6-11 carbon atoms), can be utilized by $E$. coli cells when previously induced with longer-chain fatty acids, or by strains in which expression of the fad regulon is constitutive due to mutations in the fadR gene (Klein et al., 1971; Simons et al., 1980). In contrast, other bacteria (e.g. pseudomonads) grow on fatty acids of all chain lengths, and in these cases, fatty acids of $\mathrm{C}_{6}$ or longer are effective inducers of the $\beta$-oxidation pathway (Sato et al., 1992). Our in vivo $\beta$-oxidation studies in cells grown in the presence or absence of fatty acids (Table 1), and the in vitro assays of two enzymes of the pathway, acylCoA synthetase and acyl-CoA dehydrogenase (Table 2 ), clearly indicate that $S$. coelicolor constitutively expresses the enzymes of the $\beta$-oxidation cycle, without the need for induction by a fatty acid of any chain length. Glucose repression in S. coelicolor A3(2) is known to affect expression of several genes involved in the uptake and/or utilization of many alternative carbon sources (Hodgson, 1982; Fornwald et al., 1987). Interestingly, our data indicate that the- $\beta$-oxidation pathway in this micro-organism, instead of being repressed by glucose was, at least for long-chain fatty acids, stimulated by this metabolite. This is also an important difference from E. coli, in which catabolite repression of the $\beta$-oxidation enzyme system has been described (Pauli et al., 1974).

Kinetic studies on the uptake of octanoate showed that the concentration dependence of this medium-chain fatty acid displayed a linear component which corresponds to a diffusion-like mechanism (Fig. 2b). The transport of palmitate showed a somewhat more complex pattern. The biphasic kinetics obtained indicated the existence of two or more components in the transport system for this fatty acid (Fig. 2a). Interestingly, the active component of palmitate transport became apparent only above concentrations of $100 \mu \mathrm{M}$, where the data conformed to simple Michaelis-Menten kinetics, whereas below this concentration the incorporation was directly proportional to the external concentration of palmitate. Uptake studies done in the presence of oligomycin showed concentration-dependent kinetics, probably corresponding to diffusion. The ability of oligomycin-treated cells to $\beta$-oxidize palmitate (data not shown) strengthens the idea of true diffusion of the fatty acid into the cell rather than simple non-specific binding. From these results we hypothesize that the mediated uptake of long-chain fatty acids occurs 
through a carrier protein located in the cell membrane and that a critical concentration of the substrate $(100 \mu \mathrm{M})$ is required for the system to become active. The linearity of the palmitate uptake observed between 10 and $100 \mu \mathrm{M}$ could be explained as the first step in the uptake process in which the fatty acid intercalates between the phospholipids of the membrane from where, after reaching a certain concentration, it could be translocated into the cytoplasm or the inner layer of the cytoplasmic membrane by the carrier protein. In E. coli an outer-membrane protein, FadL, essential for longchain fatty acid transport, has been described (Ginsburgh et al., 1984; Black et al., 1985; Black, 1988). However, the exact role of this protein in the uptake of long-chain fatty acids is still unknown (Clark \& Cronan, 1996).

Competition experiments with different chain-length fatty acids demonstrated specificity of the mediated transport for long-chain fatty acids, but whether this specificity corresponds to the putative carrier protein or the acyl-CoA synthetase(s), which could be different for medium or long-chain fatty acids, remains to be determined. The inhibition of palmitate uptake by several metabolic inhibitors (Table 2), demonstration of a saturable component in the uptake of this fatty acid, and the competition assays, strongly support the idea of an active component in the uptake of long-chain fatty acids.

At present there is controversy as to the mechanism and rate of transbilayer movement of fatty acids in membranes. In principle, the physical transfer of fatty acids across the cytoplasmic membrane, even for long-chain fatty acids, does not require any energy or the involvement of any protein. Kamp \& Hamilton (1992) have shown that unionized long-chain fatty acids can transit a phospholipid bilayer by a flip-flop mechanism with a half-life of $<2 \mathrm{~s}$. Ionized fatty acids, in contrast, cross the bilayer with a half-time of several minutes. Thus conversion of fatty acids to the CoA thioester could explain the overall unidirectional uptake. To obtain more insight into this subject we measured the rates of palmitate and octanoate uptake at various $\mathrm{pH}$ values. For octanoate the rate of uptake was very similar at all $\mathrm{pH}$ values assayed (Fig. 5a). Oligomycin and $\mathrm{NaF}$ did not inhibit octanoate uptake either at $\mathrm{pH} 4$ (data not shown) or at $\mathrm{pH} 7$ (Fig. 5b). These results and the kinetics of octanoate uptake at $\mathrm{pH} 7$ lead us to speculate that, independently of the ionized state of the molecule, octanoate is transported by simple diffusion. Palmitate, on the other hand, was imported at much faster rates in its unionized form ( $\mathrm{pH} 4$ ) (Fig. 5a, b). Kinetic studies at this $\mathrm{pH}$, and the use of fluoride at two different concentrations of the fatty acid and at different $\mathrm{pHs}$ (Fig. 5b, c), strongly indicate that the unionized form of this long-chain fatty acid enters the cell by simple diffusion. The fact that at $\mathrm{pH} 7$ approximately $20 \%$ of the palmitate enters the cell by simple diffusion, even when most of the fatty acid is in its ionized form, could be explained by a change in the apparent $\mathrm{pK}_{\mathrm{a}}$ of a fatty acid when it is bound to a membrane; the $\mathrm{pK}_{\mathrm{a}}$ of oleic acid in egg phosphatidylcholine vesicles is 7.6 (Hamilton \& Cistola, 1986). Therefore we concluded that palmitate (and probably other long-chain fatty acids), first bind to the cytoplasmic membrane, and the fraction that becomes protonated crosses it by simple diffusion, whereas the ionized fraction is translocated by a specific carrier protein through an active mechanism.

The stimulation of long-chain fatty acid utilization by glucose seems to occur at at least two levels: (a) by increasing the rate of uptake of the fatty acid (Fig. 4a), affecting the mediated component of the uptake system; and (b) increasing the levels of at least one of the enzymes of the $\beta$-oxidation cycle, acyl-CoA synthetase, at least sixfold. The fact that in vivo $\beta$-oxidation of palmitate increases only twofold in the presence of glucose suggests that the uptake of the fatty acid is the rate-limiting step. However, we cannot exclude the possibility that part of the acyl-CoA formed could enter into the synthesis of membrane phospholipids or triacylglycerols, which have been recently found in various Streptomyces species as storage molecules (Olukoshi \& Packter, 1994). In such a case the limiting step would occur at the level of other enzymes involved in the catabolic pathway of fatty acids.

\section{ACKNOWLEDGEMENTS}

We would like to acknowledge F. Podestá for helpful discussions during the course of this work, and A. Viale, D. Hopwood and M. Bibb for critical reading of the manuscript. This work was supported by Fundación Antorchas, the International Foundation for Science (IFS) and the National Research Council of Argentina (CONICET).

\section{REFERENCES}

Black, P. N. (1988). The fadL gene product of Escherichia coli: an outer membrane protein required for uptake of long-chain fatty acids and involved in sensitivity to bacteriphage T2. J Bacteriol 170, 2850-2854.

Black, P. N. \& DiRusso, C. (1994). Molecular and biochemical analyses of fatty acid transport, metabolism, and gene regulation by Escherichia coli. Biochim Biophys Acta 1210, 123-145.

Black, P. N., Klanian, S. F., DiRusso, C. C. \& Nunn, W. D. (1985). Long chain fatty acid transport in Escherichia coli: cloning, mapping and expression of the fadL gene. J Biol Chem 260, 1780-1790.

Clark, D. \& Cronan, J. E., Jr (1996). Two-carbon compounds and fatty acids as carbon sources. In Escherichia coli and Salmonella: Cellular and Molecular Biology, pp. 343-357. Edited by F. C. Neidhardt and others. Washington, DC: American Society for Microbiology.

Delic, I., Robbins, P. \& Westpheling, J. (1992). Direct repeat sequences are implicated in the regulation of two Streptomyces chitinase promoters that are subject to carbon catabolite control. Proc Natl Acad Sci USA 89, 1885-1889.

Fornwald, J. A., Schmidt, R. J., Adams, C. W., Rosenberg, M. \& Brawner, M. E. (1987). Two promoters, one inducible and one constitutive, control transcription of the Streptomyces lividans galactose operon. Proc Natl Acad Sci USA 84, 2130-2134.

Ginsburgh, C. L., Black, P. N. \& Nunn, W. D. (1984). Transport of long chain fatty acids in Escherichia coli. Identification of a 
membrane protein associated with the fadL gene. $J$ Biol Chem 259, 8437-8443.

Hamilton, J. A. \& Cistola, D. A. (1986). Transfer of oleic acid between albumin and phospholipid vesicles. Proc Natl Acad Sci USA 83, 82-86.

Hodgson, D. (1982). Glucose repression of carbon source uptake in Streptomyces coelicolor A3(2) and its perturbation in mutants resistant to 2-deoxyglucose. J Gen Microbiol 128, 2417-2430.

Hopwood, D. A., Kieser, T., Wright, H. M. \& Bibb, M. J. (1983). Plasmids, recombination and chromosome mapping in Streptomyces lividans 66. J Gen Microbiol 129, 2257-2269.

Hopwood, D. A., Bibb, M. J., Chater, K. F., Kieser, T., Bruton, C. J., Kieser, H. M., Lydiate, M. J., Smith, C. P., Ward, J. M. \& Schrempf, H. (1985). Genetic Manipulation of Streptomyces: a Laboratory Manual. Norwich: John Innes Foundation.

Hopwood, D. A., Chater, K. F. \& Bibb, M. J. (1994). Genetics of antibiotic production in Streptomyces coelicolor A3(2), a model streptomycete. In Genetics and Biochemistry of Antibiotic Production, pp. 65-102. Edited by L. C. Vining \& C. Stuttard. Philadelphia: Butterworth-Heinemann.

Kamp, F. \& Hamilton, J. (1992). pH gradients across phospholipid membranes caused by fast flip-flop of unionized fatty acids. Proc Natl Acad Sci USA 89, 11367-11370.

Klein, K., Steinberg, R., Fietchen, B. \& Overath, P. (1971). Fatty acid degradation in Escherichia coli. An inducible system for the uptake of fatty acids and further characterization of old-mutants. Eur J Biochem 19, 4281-4290.

Korn-Wendisch, F. \& Kutzner, H. J. (1991). The family Streptomycetaceae. In The Prokaryotes, pp. 921-995. Edited by A. Balows, H. Trüper, M. Dworkin, W. Harder \& K. Schleifer. New York: Springer.

Miyashita, K., Fujii, T. \& Sawada, Y. (1991). Molecular cloning and characterisation of chitinase genes from Streptomyces lividans 66. Gene 137, 2065-2072.

Nunn, W. D. (1986). A molecular view of fatty acid catabolism in Escherichia coli. Microbiol Rev 50, 179-192.

Nunn, W. D., Simons, R. W., Egan, P. A. \& Maloy, S. R. (1979). Kinetics of the utilization of medium and long-chain fatty acid degradation by a mutant of Escherichia coli defective in the fadL gene. J Biol Chem 254, 9130-9134.

Olukoshi, E. R. \& Packter, N. M. (1994). Importance of stored triacylglycerols in Streptomyces: possible carbon source for antibiotics. Microbiology 140, 931-943.

Overath, P., Raufuss, E. M., Stoffel, W. \& Ecker, W. (1967). The induction of the enzymes of fatty acid degradation of Escherichia coli. Biochem Biophys Res Commun 29, 28-33.

Overath, P., Pauli, G. \& Schairer, H. U. (1969). Fatty acid degradation in Escherichia coli. An inducible acyl-CoA synthe- tase, the mapping of old-mutations, and the isolation of regulatory mutants. Eur J Biochem 7, 559-574.

Pauli, G., Erhing, R. \& Overath, P. (1974). Fatty acid degradation in Escherichia coli: requirement of cyclic adenosine monophosphate and cyclic adenosine monophosphate receptor protein for enzyme synthesis. $J$ Bacteriol 117, 1178-1183.

Peczynska-Czoch, W. \& Mordarski, M. (1988). Actinomycete enzymes. In Actinomycetes in Biotechnology, pp. 220-283. Edited by M. Goodfellow, S. T. Williams \& M. Mordarski. San Diego, CA: Academic Press.

Pérez, C., Juárez, K., Garcla-Castells, E., Soberón, G. \& ServínGonzalez, L. (1993). Cloning, characterization, and expression in Streptomyces lividans 66 of an extracellular lipase-encoding gene from Streptomyces sp. M11.Gene 123, 109-114.

Robbins, P. W., Overbye, K., Albright, C., Benfield, B. \& Pero, J. (1992). Cloning and high-level expression of a chitinase-encoding gene of Streptomyces plicatus. Gene 111, 69-76.

Sato, S., Imamura, S., Ozeki, Y. \& Kawaguchi, A. (1992). Induction of enzymes involved in fatty acid beta-oxidation in Pseudomonas fragi B-0771 cells grown in media supplemented with fatty acid. J Biochem 111, 16-19.

Servín-González, L. \& Bibb, M. J. (1994). Transcriptional regulation of the four promoters of the agarase gene (dagA) of Streptomyces coelicolor A3(2). Microbiology 140, 2555-2565.

Simons, R. W., Egan, P. A., Crute, H. T. \& Nunn, W. D. (1980). Regulation of fatty acid degradation in Escherichia coli: isolation and characterization of strains bearing insertion and temperaturesensitive mutations in gene fadR. J Bacteriol 142, 621-632.

Smith, C. P. \& Chater, K. F. (1988). Structure and controlling sequences for the Streptomyces coelicolor glycerol operon. J Mol Biol 204, 569-580.

Stackebrandt, E., Liesack, W. \& Witt, D. (1992). Ribosomal RNA and rDNA sequence analysis. Gene 115, 255-260.

Tanaka, T., Hosaka, K. \& Numa, S. (1979). Purification and properties of long-chain acyl-coenzyme-A synthetase from rat liver. Eur J Biochem 98, 165-172.

Takano, E., Gramajo, H. C., Strauch, E., Andres, N. \& Bibb, M. J. (1992). Transcriptional regulation of the redD transcriptional activator gene accounts for growth-phase-dependent production of the antibiotic undecylprodigiosin in Streptomyces coelicolor A3(2). Mol Microbiol 6, 2797-2804.

Virolle, M. J. \& Bibb, M. J. (1988). Cloning, characterization and regulation of an $\alpha$-amylase gene from Streptomyces limosus. Mol Microbiol 2, 197-208.

Weast, R. C. (1973). Handbook of Chemistry and Physics, D-129. Cleveland, OH: CRC Press.

Received 12 December 1996; revised 4 March 1997; accepted 11 March 1997. 